\title{
The Third Soviet Emigration, 1948-91
}

\author{
Sidney Heitman
}

\begin{abstract}
Since the end of World War II, more than one and a half million citizens of the U.S.S.R. have emigrated to the West in a unique and unprecedented movement called the "the Third Soviet Emigration." Notwithstanding the political and international importance of this exodus, it is not well known or understood today because it has not been adequately studied until now. This article is intended to improve our understanding of the Third Soviet Emigration by examining its background, evolution and dynamics.
\end{abstract}

\section{Introduction ${ }^{1}$}

Since the end of World WarII, more than one and a half million citizens of the U.S.S.R. have emigrated to the West in a unique and unprecedented movement called the "Third Soviet Emigration." In contrast to preceding waves of refugees from war and revolution, the Third Emigration has been a legal, organized and sustained movement of mainly three national minorities-Jews, ethnic Germans and Armenians. Jews have resettled mainly in Israel and the United States, Germans in Germany and Armenians in the United States.

The origins of the exodus go back to the early postwar years, but the vast majority of emigrants left after 1970, when the Soviet government relaxed for a time its historic antipathy to its citizens' free movement. Emigration was sharply restricted between 1980 and 1986, but in 1987 the exodus revived and attained unprecedented levels, while new groups besides Jews, Germans and Armenians joined the flight, altering its composition, dynamics and patterns of resettlement. These changes resulted from changes in emigrants' motives for leaving and in the policies of the U.S.S.R. and the countries of destination towards them, which not only transformed the movement after 1985 but continue to shape post-Soviet emigration today.

The Third Emigration is of wide interest because of its profound significance for the emigrants and its political importance for the U.S.S.R. and the West. For the emigrants, the movement has been literally life-altering. Not only have

Professor Sidney Heitman was a professor of History at Colorado State University and a member of the editorial advisory board of Refuge. they successfully escaped from conditions they considered inimical to undertake the hazards and hardships of emigrating and resettling in foreign places, but they have, for the most part, successfully established new lives and identities in the free and open West. At the same time, the exodus has played a major role in internal Soviet politics and foreign policy, particularly since the advent of detente.

Throughout the 1970s, the levels and composition of Soviet emigration quotas were widely viewed as a barometer of East-West relations and a measure of Soviet compliance with its human rights obligations under a number of international agreements the U.S.S.R. has signed. Between 1980 and 1989, the question of emigration figured centrally in negotiations between the U.S.S.R. and the West over such major issues as nuclear arms control, mutual trade and exchanges, and the resolution of regional conflicts, with progress towards resolving them directly linked by the West to the Soviet record on emigration. Since the dissolution of the U.S.S.R., post-Soviet-or so-called "fourth wave" -emigration continues to be a major concern of both the successor states and the West and cannot be properly understood without an awareness of the movement that preceded it. Notwithstanding its interest and importance, however, the Third Emigration is not as well known or understood as it should be because it has not been thoroughly studied until now. Virtually nothing has been written in the former U.S.S.R. on what has been a taboo subject until recently, and though there is a large body of Western literature dealing with various aspects of the movement, these works are limited in scope and of uneven quality and reliability. As a result, important questions concerning the exodus have few or no answers, and the significance of recent changes in the movement and their implications for the future are not adequately understood. ${ }^{2}$

The purpose of this article is to provide a better awareness of the Third Emigration. It is based on research in libraries, archives and private collections in the United States, Europe and Israel, and on information provided by various Western specialists, officials and informants. Though new information on the subject is now becoming available, most of this study was conducted before the breakup of the U.S.S.R. and had to depend primarily on non-Soviet sources of information.

Of the many questions raised by the Third Emigration, this article is concerned for the present with its history, dynamics and consequences. Specifically, it deals with four aspects of the movement, namely (1) the background and special character of the Third Emigration; (2) the evolution of the exodus from its origins in 1948 to the dissolution of the Soviet state in 1991; (3) the causes and dynamics of emigration; and (4) Soviet emigration policy and its determinants.

\section{Background and Character of the Third Emigration}

At the outset, certain unique characteristics of the so-called "Third Emigration" need to be clarified. First, it should be noted that the term itself is a misnomer, for the exodus of Soviet Jews, Germans, Armenians and others since World War II is not the third such movement but the first. This is not simply a semantic distinction, but one of substance and importance.

Refuge, Vol. 13, No. 2 (May 1993) 
From the inception of the Soviet regime to the present, some twenty million persons have migrated from the U.S.S.R. in a series of movements of various types. To place the Third Emigration in historical perspective, Table 1 lists thirty-one selected out-migrations involving around thirteen million persons and ranging from the flight of refugees, the repatriation of citizens of othercountries, the transfer of populations resulting from geopolitical changes and forcible expulsions to voluntary emigration per se (see Table 1). Two of these external population movements have come to be known in the Western literature of Soviet history as the "first" and "second" emigrations-namely, the flight of $1.5 \cdot \mathrm{mil}-$

Table 1: Selected Migrations From the U.S.S.R. Since 1917

Migration Movement

1. Russian refugees from revolution civil war and famine

2. European refugees from the same

3. Polish refugees, displaced persons and repatriates to Poland

4. German emigrants escaping forced collectivization

5. Jewish refugees and displaced persons

6. Jewish emigrants

7. German Mennonite, Lutheran and Catholic emigrants

8. Swedish repatriates

9. Germans transferred from Soviet territory under terms of the Nazi-Soviet Non-Aggression Pact

10. World War II Russian refugees and displaced persons

11. Karelian Finns transferred to Finland

12. Ukrainian displaced persons

13. Estonian, Latvian and Lithuanian refugees and displaced persons

14. Swedish repatriates from Estonia and Latvia to Sweden

15. Ingermanlanders transferred to Finland

16. Germans expelled from East Prussia

17. Poles transferred from prewar eastern Poland to postwar Poland

18. Czechs and Ukrainians transferred from Volhynia and Carpatho-Ukraine to Czechoslovakia

19. Repatriated prisoners of war and captive forced labourers

20. Defectors, escapees, self-exiles, binational spouses, exchanged spies and prisoners, etc.

21. Jews transferred to Poland

22. Jewish legal emigrants

23. Germans transferred from East Prussia and Memel

24. German legal emigrants

25. Armenian legal emigrants

26. Polish repatriates (including 14,000 Jews)

27. Spanish repatriates

28. Greek repatriates

29. Korean repatriates

30. Pontic Greek legal emigrants

31. Evangelical and Pentecostal legal emigrants
Estimated No. of Persons

$1,500,000$

250,000

$1,500,000$

5,600

33,500

70,000

21,000

900

396,000

$2,000,000$

415,000

150,000

$2,300,000$

6,000

18,000

500,000

$4,000,000$

Time

Frame

1917-22

1918-22

1918-25

1920

1921-25

1922-41

1923-26

1928-29

1939-41

1939-45

1940-44

1941-45

1941-47

1942-43

1943-45

1944-45

1944-47

63,000

1945-47

unknown

1945-?

unknown

50,000

789,400

3,000

563,400

87,600

250,000

5,500

5,500

3,500

37,300

25,700 lion refugees from the revolutions of 1917 and its aftermath, and of two million displaced persons during World WarII (see items 1 and 10, Table 1).

Why these two refugee movements are called "emigrations" when they do not fit the usual conception of a historic emigration per se is not clear. Nor is it clear why they have been given consecutive numerical designations even though they are separated by twenty years and by other migrations. It is also not clear why the exodus of Jews, Germans and Armenians since 1948 is called the "Third Emigration" as though it has some sequential or functional relation to the other two, which it does not. The fact is that the so-called Third Emigration is not like any other movement but is unique and unprecedented and therefore the first such exodus since 1917. If it has an affinity with a preceding emigration, it is with the exodus of Jews, Germans and others from the Russian empire in the late nineteenth and early twentieth centuries, but not with those after 1917. This distinction is important because it raises questions concerning the causes, dynamics and consequences of the so-called Third Emigration that do not arise with other movements. Notwithstanding the inaccuracy of the term, however, I will use it herewith the provisos noted rather than coin a new term that would confuse the issue further.

A second distinctive characteristic of the Third Emigration is that it proceeded for more than forty years despite the fact that it ran contrary to Soviet policy concerning free movement by citizens of the U.S.S.R. and in the absence of a legal right to do so. To emphasize these points, it is useful to cite two authorities on the subject of Soviet emigration. Alan Dowty, a specialist on international migration, has written:

Soviet opposition to emigration ... grows out of historical traditions of isolation and immobility and basic aspects of Marxism in the Russian setting: the focus on state power and the collective interest, the call for mobilization of the entire public, the sense of being besieged by a hostile world, the belief that departure is an act of betrayal, the instinctive closure of comPost-Stalin Era," Soviet Jewish Affairs 13, no. 1 (1983): 3-36; Eugene M. Kulischer, Europe on the Move: War and Population Changes, 1917-1947 (New York: Columbia University Press, 1948); and Z. Alexander, Immigration to Israel from the USSR (Tel Aviv: Faculty of Law, Tel Aviv University, 1977). 
munication with the outside, the reservation of foreign travel-as in the time of Catherine the Great-as an elite privilege. As elsewhere in post-World War II Eastern Europe, it was reinforced by war losses, a declining birth rate, labor shortages, and ethnic considerations. $^{3}$

Nonetheless, since 1948 more than one and a half million Soviet citizens were permitted to emigrate legally to the West. Writing in 1975, George Ginsburgs, a specialist on Soviet constitutional law at Rutgers University School of Law, explained this apparent anomaly as follows:

To appreciate the problem properly, one must bear in mind that, in Soviet Law, a citizen does not possess a right to emigrate at will. To be sure, the concept of emigration is not unfamiliar to Soviet authorities. Thus, the Regulations on Entry into the USSR and Exit from the USSR ... of 19 June, 1959, no. 660 , specify that exit from the USSR of Soviet citizens is permitted on the strength of passports for travel abroad or substitute documents accompanied by an exit visa furnished by the union of Republican Ministries of Foreign Affairs, diplomatic missions of the USSR Ministry of Foreign Affairs, the Ministries of Internal Affairs of the USSR, the union and Autonomous Republics, and their organs, depending on the official position of the interested citizen, his passport category, and location at the time of issuance of the visa.... Exit visas are issued in accordance with the established procedure on the basis of a written petition from the individual citizen desiring to go abroad on private business. Special instructions for the application of these Regulations, with respect to the issuance of documents and visas by the USSR Ministry of Foreign Affairs and its subordinate agencies, were to be issued by the USSR Ministry of Foreign Affairs in consultation with the USSR Ministry of internal Affairs and its affiliates in the Republics and Autonomous Republics was to depend on rules laid down by the USSR Ministry of Foreign Affairs, the Committee on State Security and the Ministry of Defence.

The obvious implication of the directive is that exit from the USSR, even permanent residence is both possible and legitimate-whenever the competent institutions approve a personal request to that effect. The last word, however, rests with the administrative authorities, and without their consent, the application must fall. What is more, the Regulations do not indicate what criteria govern the whole process, presumably leaving these to be defined by the aforementioned supplementary departmental instructions, but meanwhile furnishing the average citizen wanting to depart from the USSR no clue as to how the system is supposed to operate, what type of official treatment his bid might encounter, and what results he can expect.

Hence, where, on a number of occasions, an opportunity to leave the USSR has been granted to specific categories of Soviet nationals, the episodes have duly been viewed as unique concessions and not symptomatic of any public recognition of the inherent freedom of the individual to emigrate. Inasmuch, then, as Soviet law has sanctioned the emigration of various people over the years, the phenomenon represents, and locally has always been perceived as, an incidence of political dispensation constituting a special privilege conferred on the interested party by the organs of the state and not something that a person can claim unilaterally independently of or in opposition to the regime's express wishes. ${ }^{4}$

The 1959 regulations were revised twice-once in 1970 and again in 1986. The 1970 revisions, adopted in anticipation of a substantial increase in Jewish emigration, added fees and charges to the emigration process, but did not alter the provisions of the 1959 regulations. The 1986 modifications, issued on the eve of a meeting of the signatories to the Helsinki accords of 1975 in Vienna to review compliance with their human rights provisions, also changed no basic provisions of the 1959 regulations, but only simplified and streamlined some of the emigration procedures. Thus, until recently, emigration historically has been a privilege dispensed or withheld by the Soviet government at its discretion in an arbitrary, unpredictable and ambiguous manner. The departure of more than one and a half million Soviet citizens for the
West since 1948, therefore, is a legal aberration rather than a norm, permitted by the authorities because of perceived benefits to the state at various times, not because of a commitment to basichuman rights. In May 1991 a new law was adopted by the Supreme Soviet of the U.S.S.R., making emigration a legal right for all Soviet citizens, but its status was ambiguous for a long time because its effective date was deferred to January 1993.

A third distinctive characteristic of the Third Emigration is the fact that the privilege of leaving the U.S.S.R. has been granted until recently almost entirely to only three groups of citizens based on their ethnicidentity, namely Jews, ethnic Germans and Armenians. Recently Pontic Greeks and Evangelical and Pentecostal Christians have also been permitted to emigrate, but their numbers are small compared to the others. It should also be noted that even when these groups were permitted to leave, their departure was officially justified as special cases involving repatriation or family reunification so as to sidestep the antipathy to emigration per se and to avoid establishing a precedent of free movement that others might seek to follow. Thus, until the adoption of the 1991 law on foreign travel-and even since then-emigration has been disguised by the Soviet authorities and treated as a unique concession to only selected Soviet citizens for reasons and in ways that will be seen below.

With these distinctive characteristics of the Third Emigration in mind, the discussion now turns to the evolution of the movement from 1948 through the end of 1991.

\section{Evolution of the Third Emigration}

Viewed in historical perspective, the Third Emigration has passed through four stages since its inception, each marked by changes in the numbers, ethnic composition, motives and destinations of the emigrants, on the one hand and in the policies of the Soviet government and the countries of resettlement towards them on the other (see Table 2).

The first stage (1948-70) was one of relatively low levels of emigration dur- 
ing which only 59,600 persons, or 4 percent of the 1,507,600 total emigrants who left the U.S.S.R. through the end of 1991, emigrated over a span of twenty-three years for an average annual exodus of 2,600 persons. The second stage (1971-80) was one of greatly expanded emigration, during which nearly one-fourth of the total emigrants left the Soviet Union $(347,300$ persons, or 23 percent) for an annual average of 34,700 persons. The third stage (1981-86) saw a sharp reduction in emigration when only 44,100 persons left the U.S.S.R., or 2.9 percent of the total, for an annual average of 7,300 individuals. The fourth period was one of unprecedented levels of emigration, during which more than one million persons emigrated between 1987 and the end of 1991 , or nearly threefourths (70.1 percent) of the total, for an annual average of 211,300 emigrants.

After 1991 the numbers, composition, destinations and other aspects of the movement changed greatly, reflecting the deep changes that swept the former Soviet Union and raising questions as to whether these developments were essentially an extension of the fourth stage of the Third Emigration or the start of a new and substantively different "fourth wave" of Soviet emigration.

Table 3 summarizes the results of the resettlement of Soviet emigrants from 1948 through the end of 1991 . It should be noted that until the research for this article was undertaken, there was no composite tally anywhere of emigrant destinations such as the listing presented in Table 3. During the first stage of the exodus, all Jewish emigrants went to Israel, except for 14,000 Polish Jews who were permitted to return to their homes in Poland. During the second stage, only two-thirds of them resettled there, the remainder going mainly to the United States. In the third and fourth stages, increasing numbers of them chose the United States over Israel (see Table 3).

Overall, between 1948 and 1991, 518,600 Jews ( 65.9 percent) resettled in Israel, 223,900(28.4 percent) in theUnited States and 46,900 in other countries (5.9 percent).

All German emigrants resettled in West Germany between 1948 and 1989, except 1,000 persons who went to the GDR in the 1980s, but who were integrated into the unified Federal Republic in 1990. Armenians resettled in France, the United States, the Middle East, Greece and elsewhere, while Evangelicals and Pentecostals went mainly to the United States and Greeks to Greece. Table 3 lists and analyses these resettlement patterns.

\section{Causes and Dynamics of Emigration}

Turning to the causes and dynamics of Soviet emigration, the discussion deals with each of the emigrant groups in turn.

\section{Jewish Emigration ${ }^{5}$}

On the eve of the rise in Jewish emigration in the early 1970s, there were an estimated two million Jews in the U.S.S.R. consisting of three main groups-Asiatic, Western and so-called "core" or "heartland" Jews. Asiatic Jews lived in Central Asia and the Caucasus region, where they observed traditional cultures and religious practices. Western Jews, who were more numerous and lived in territories annexed by the Soviet Union during World War II (the Baltic region, eastern Poland and Bessarabia), also followed traditional culture and religion and were, moreover, strongly Zionist. The largest group was the core or heartland Jews, who had lived in European Russia since 1917 and were by 1971 largely Russionized, secular and integrated. Small groups of Jews lived elsewhere in the U.S.S.R. (such as in Birobidjan), but most emigrants came from the three main groups.

Soviet Jews in 1971 were overwhelmingly urban, well educated and disproportionately representedin professional, scientific and creative occupations, which made them valuable to the Soviet authorities, but did not shield them from discrimination and persecution. Despite their circumstances, however, they had learned to adapt, for there could be no thought of leaving the U.S.S.R. and no place to go even if it had been possible to do so.

To be sure, between 1948 and 1970 several thousand elderly and infirm Jews were permitted to join relatives in Israel as a result of pressure from the Israeli government, and 14,000 Polish Jews

\section{Table 2: Soviet Emigration by Stages, 1948-91}

\begin{tabular}{|c|c|c|c|c|c|c|c|c|c|}
\hline Period & Jews & Germans & Armenians & Greeks & $\begin{array}{l}\text { Evang. and } \\
\text { Pentecostal }\end{array}$ & Others & $\begin{array}{l}\text { Period } \\
\text { Totals }\end{array}$ & $\begin{array}{l}\text { Proportion } \\
\text { of Total (\%) }\end{array}$ & $\begin{array}{l}\text { Annual } \\
\text { Average }\end{array}$ \\
\hline $1948-70$ & 25,200 & 22,400 & 12,000 & - & - & - & 59,600 & 4.0 & 2,600 \\
\hline $1971-80$ & 248,900 & 64,300 & 34,000 & - & - & - & 347,200 & 23.0 & 34,700 \\
\hline $1981-86$ & 16,900 & 19,500 & 6,400 & 1,300 & - & - & 44,100 & 2.9 & 7,300 \\
\hline $1987-91$ & 498,400 & 456,800 & 35,200 & 36,000 & 25,700 & 4,600 & $1,056,700$ & 70.1 & 211,300 \\
\hline Totals & 789,400 & 563,000 & 87,600 & 37,300 & 25,700 & 4,600 & $1,507,600$ & 100.0 & \\
\hline $\begin{array}{l}\text { Proportion } \\
\text { of Total (\%) }\end{array}$ & 52.4 & 37.3 & 5.8 & 2.5 & 1.7 & 0.3 & 100.0 & & \\
\hline
\end{tabular}


were repatriated to postwar Poland as part of the massive population transfers following World War II (see Table 1), but these were exceptional cases that did not alter the official proscriptions on voluntary emigration per se. The rationale of family reunification set a precedent, however, that was later invoked by the Soviet authorities to justify emigration by Jews and others in the 1970s.

In the late 1960 s and early 1970 s three factors changed the status of Soviet Jews. One was the rise of a virulent new wave of official persecution in the U.S.S.R. that caused alarm within the country and alerted the West to the plight of Jews in the Soviet Union.

The second was the stunning Israeli victory in the 1967 Six-Day War, which stirred Jewish pride and consciousness throughout the world, including the U.S.S.R. The third was the advent of detente, which led to a relaxation of East-West relations and of internal Soviet political controls.

These developments encouraged at first a few and then a growing number of Soviet Jews to apply to emigrate to Israel on the grounds of family reunification recognized earlier by the government and supported by several international human rights agreements the U.S.S.R. had signed. Surprisingly, the Soviet authorities were amenable and relaxed the ban on leaving the country for thousands of Jews who ostensibly sought to rejoin relatives from whom they had been separated by the war and its aftermath.
The first toleave were from the Soviet periphery-Asiatic and Western Jews, who went to Israel not only to escape persecution but also out of religious and Zionist motives. From the mid-1970s onward, however, a growing number of core Jews joined the exodus, not only to avoid discrimination but also to find better personal and economicopportunities in the West. These emigrants increasingly "dropped out" in Vienna and other transit points en route to Israel and resettled mainly in the United States, where they were offered sanctuary as political refugees.

When detente broke down in the early 1980s, the Soviet government sharply reduced Jewish (and other) emigration until 1987, when emigration levels rose again, attaining unprecedented levels. By this time most Jewish emigrants were clearly economic migrants who chose to resettle mainly in the United States, until the American government imposed immigration limits in 1990 , diverting them then to Israel. Table 3 shows the cumulative results of these shifting patterns of resettlement.

\section{German Emigration $^{6}$}

The two million ethnic Germans in the U.S.S.R. on the eve of the exodus of the 1970 s were, like the Jews, a dispersed, alienated national minority with a history of persecution under the tsars and Soviets. Descendants of colonists invited to Russia by Catherine the Great and Alexander I in the late eighteenth and early nineteenth centuries, they consisted of two main groups - the Volga Germans and Black Sea Germans, named for the regions where they settled.

For a century after their arrival, the colonists flourished, enjoyed favours and exemptions from the state, and grew in numbers. In the late nineteenth century, they experienced economic reverses and lost their privileged status, forcing thousands of them to emigrate to the New World (paralleling the flight of Russian Jews and others from Russia). Those who remained suffered successive catastrophes during World War I, the revolutions of 1917 and the civil war and famine that followed, as well as Stalin's collectivization drive and terror in the 1930s.

There was a brief respite in the 1920 s during NEP, when a Volga German republic and several autonomous German districts were created, in which a vigorous national cultural and religious life flourished for a time. Ethnic Germans also participated in Soviet politics and held important posts in the Communist party.

World War II ended all organized German life. When the Nazis invaded the U.S.S.R. in 1941, Stalin accused the Soviet Germans of treason and ordered them deported to the east. Six hundred thousand Volga Germans were sent to forced labour camps in Siberia and Central Asia and confined under inhuman conditions. Their autonomous units

\begin{tabular}{|c|c|c|c|c|c|c|c|c|c|c|c|c|}
\hline \multicolumn{13}{|c|}{ Table 3: Destinations of Emigrants by Nationality, 1948-91 } \\
\hline Years & Israel & $\begin{array}{l}\text { Jews } \\
\text { U.S. }\end{array}$ & Other & FRG & Germans & ns U.S. & \multicolumn{2}{|c|}{$\begin{array}{l}\text { Armenians } \\
\text { France Other }\end{array}$} & \multirow{2}{*}{$\begin{array}{c}\text { Greeks } \\
\text { Greece } \\
-\end{array}$} & \multicolumn{2}{|c|}{$\begin{array}{l}\text { Evan. \& Pent. } \\
\text { U.S. Canada }\end{array}$} & \multirow{2}{*}{$\begin{array}{r}\text { Other } \\
\text { U.S. } \\
-\end{array}$} \\
\hline $1948-70$ & 11,200 & - & 14,000 & 22,400 & 一 & - & 12,000 & - & & - & 一 & \\
\hline $1971-80$ & 156,300 & 83,400 & 9,200 & 63,300 & 1,000 & 34,000 & - & - & - & - & - & - \\
\hline $1981-86$ & 8,200 & 7,800 & 900 & 19,500 & - & 6,400 & - & - & 1,300 & 100 & - & - \\
\hline $1987-91$ & 342,900 & 132,700 & 22,800 & 456,800 & - & 34,400 & - & 800 & 36,000 & 25,400 & 200 & 4,600 \\
\hline Totals & 518,600 & 223,900 & 46,900 & 562,000 & 1,000 & 74,800 & 12,000 & 800 & 37,300 & 25,500 & 200 & 4,600 \\
\hline $\begin{array}{l}{ }^{a} \text { Other } \\
{ }^{b} \text { Other }\end{array}$ & $\begin{array}{l}\text { ces where } \\
\text { ces where }\end{array}$ & $\begin{array}{l}\text { Jews have } \\
\text { Armenians }\end{array}$ & $\begin{array}{l}\text { ttled in } \\
\text { settled }\end{array}$ & $\begin{array}{l}\text { Canada, } \\
\text { the Mid }\end{array}$ & $\begin{array}{l}\text { rope, Lat } \\
\text { e East, G }\end{array}$ & $n$ Amer & $\begin{array}{l}\text { Dceania. } \\
\text { herlands. }\end{array}$ & Sourc & See Table & & & \\
\hline
\end{tabular}

Refuge, Vol. 13, No. 2 (May 1993) 
were abolished, their property was confiscated and their cultural and religious organizations were closed. The BlackSea Germans were overrun by the Nazis before they too could be deported, and 250,000 of them were evacuated by the German government, resettled in Poland and incorporated into the Third Reich. After the war, all but 100,000 of them were forcibly returned to the U.S.S.R., where they were deported to the labour camps in the east.

Though the end of the war ended the pretext for their internment, the Germans were confined to the camps for another decade and released only in 1955 as a result of West German Chancellor Konrad Adenauer's intercession on their behalf. They were permitted to resettle in southwestern Siberia and Central Asia, but they were prohibited from returning to their former homes or seeking restitution for lost lives and property. In 1964, the Soviet government granted them an amnesty absolving the Germans of the wartime charge of collective treason, but the restrictions remained in force. Their circumstances gradually improved thereafter, particularly their economic status, for their diligent labour in agriculture and industry was highly valued and well rewarded by the Soviet regime.

However, they resented their continuing disabilities and the prohibitions against restoring their prewar status and property. Fearful of renewed persecution, some Germans sought to assimilate into Soviet society, while others joined dissident movements. Still others, however, inspired by the example of Soviet Jews who were emigrating to Israel in the early 1970s, also sought to escape the U.S.S.R. by returning to their "historic homeland" in West Germany.

Like the Jews, during the 1950s and 1960s several thousand Germans had been permitted to emigrate to the Federal Republic under pressure from Bonn. To disguise the exodus and prevent setting a precedent for general emigration, the Soviet government justified it on the grounds of "repatriating" former German citizens and the reuniting of families separated by the war. By 1968, these early transfers came to an end when rela- tions between Moscow and Bonn cooled (see Table 1).

In 1969-70, the issue of Soviet German emigration arose anew. Willy Brandt, the new chancellor of West Germany, inaugurated a new Ostpolitik and used the rapprochement with the U.S.S.R. to press for, among other things, freer emigration by Germans. At the same time, a group of Volga Germans who had been rebuffed in an effort to have their prewar autonomous republic restored, despaired of improving their lot in the U.S.S.R. and sought to emigrate en masse to West Germany. With the thaw brought about by Ostpolitik and detente, Moscow sought West German favour and opened the gates of emigration for Soviet Germans as it was also doing for Jews. Between 1971 and 1980, a total of more than 64,000 Germans emigrated from the U.S.S.R.-more than a tenfold increase over the preceding decade. After 1980 the erosion of detente led to a sharp decline in German (as well as Jewish and Armenian) emigration, but after 1987 the exodus revived and attained unprecedented levels. By the end of 1991, a total of 563,000 had left the U.S.S.R. since 1948, all of them resettling in West Germany (see Tables 1 and 2).

\section{Armenian Emigration ${ }^{7}$}

The causes of Armenian emigration are distinct from those of Jewish and German emigration (though not unrelated) because the status of Armenians in the Soviet Union in the 1970 s was unique. Since 1920, when ashort-lived independent Armenian republic was annexed by the Soviet Union, there has been a nominally sovereign Armenia in the U.S.S.R. According to the 1979 Soviet census, 4.15 million of the world's five million Armenians lived in the Soviet Union, 70 percent of them in their own national republic. Within the Armenian S.S.R., Armenians comprised 90 percent of the population, spoke their native tongue, and observed their cultural, national and religious customs with a high degree of freedom, compared to other ethnic minorities in the U.S.S.R. They also governed themselves, albeit under the guidance of the Communist party, in which native Armenians held high of- fices; until recently, the Armenian S.S.R. was one of the most prosperous republics in the Soviet Union. There were also many well-educated Armenians who boasted a rich cultural legacy and ranked high in scientific, creative and intellectual achievements.

Why then did thousands of Armenians seek to leave the U.S.S.R.? Atfirst, the impetus for emigration came not from native Armenians but from immigrants to the Armenian S.S.R. during the postwar years who had answered a call by the Soviet authorities to former nationals and others to return and help rebuild the country. Among those who arrived between 1946 and 1960 were 250,000 Armenians living in Europe, the Middle East, North Africa and the Americas. Though they had never lived in the U.S.S.R., they considered Soviet Armenia their historic homeland and religious centre and were attracted by Soviet promises of generous aid and hospitality.

Instead of housing, jobs and assistance, however, they found a backward, undeveloped country peopled by uneducated and impoverished peasants who spoke a different dialect and were openly hostile to the newcomers. They were forcibly billeted in the homes of resentful natives or makeshift shelters; their money and other valuables were confiscated; and they were barred from desirable positions in the economy and administration by jealous local officials, notwithstanding their education and skills. When they protested the breach of faith, thousands of them were imprisoned or exiled.

As a result of their treatment, the immigrants remained apart from the local inhabitants, nursed their grievances and looked for an opportunity to return to the West. Though they made importantcontributions to the postwareconomicboom that transformed the sleepy Caucasian republic into a modern, productive region and profited in the process, they knew they could do better in the West and awaited a chance to leave.

Such an opportunity arose in the 1950s for 12,000 Armenians, who had immigrated from France, when the French government pressured the Soviet government to permit them to return to 
their former homes. Anxious to accommodate the French at the time, Moscow permitted the petitioners to leave on the grounds of "repatriating" former citizens of another country so as to avoid the official proscriptions against emigration perse.

This movement ended by 1960 , but those Armenians whoremained awaited an opportunity to follow, which arose when the Soviet government eased requirements for emigration for Jews and Germans in the early 1970s on the ostensible grounds of family reunification. Armenians could also qualify for family reunification because they left members of their large extended families in the West when they emigrated to the U.S.S.R., and they began to apply in growing numbers for the right to leave. Surprisingly, the Soviets allowed them to join the Jewish and German exodus, and Armenian emigration peaked in 1980 with 14,000 persons. Immediately thereafter, the wave declined along with Jewish and German emigration, but, like the two other groups, the number of Armenians who left the U.S.S.R. rose again after 1987 (see tables 1 and 4). Except for the group that went to France, most other Armenians resettled in the United States.

Beginning around 1985, two other groups joined Jews, Germans and Armenians in emigrating from the U.S.S.R.namely Pontic Greeks and Evangelical and Pentecostal Christians (sometimes referred to collectively, though inaccurately, as "Soviet Baptists").

\section{Pontic Greek Emigration ${ }^{8}$}

The 1989 Soviet census reported 344,000 Pontic Greeks living in fourteen union republics of the U.S.S.R., but unofficial estimates place the number today at 500,000 to one million. These Soviet citizens are descendants of Greek colonists who settled the southern shore of the Black Sea (Euxine Pontusin in ancient Greek) during the eighth century B.C., where they were overrun by successive waves of invaders. In the nineteenth and twentieth centuries, they were persecuted by the Turks and fled across the BlackSea to Russia. Many Pontic Greeks supported the Bolsheviks in 1917 and were rewarded with three autonomous units, in which Greek cultural life flourished until the 1930s when Stalin brutally exiled them to Central Asia and resettled them among hostile Muslim populations. According to some estimates, a third of a million Greeks perished during this time. Perestroika and glasnost improved the status of the Pontic Greeks, but they were so alienated by then that the decline of the Soviet economy and the rise of ethnic conflict in the U.S.S.R. in the late 1980 s impelled them toleave the country in emulation of the Jews and Germans; like them, they were one of the few national minorities with a native "homeland" outside the Soviet Union, though they had left it more than two millennia ago.

The Greek government gladly interceded on their behalf and received them as "repatriates" because it was anxious to stem the "shrinking of Hellenism" resulting from declining birth rates in Greece and the loss of ethnic identity among Greek communities abroad. During the early 1980 s only a few hundred Pontic Greeks succeeded in leaving the Soviet Union, but in 1988 the number

\begin{tabular}{|c|c|c|c|c|c|c|}
\hline \multicolumn{7}{|c|}{ Table 4: Annual Soviet Emigration, 1987-91 } \\
\hline Year & Jews & Germans & Armenians & Greeks & $\begin{array}{l}\text { Evangelical \& } \\
\text { Pentecostal }\end{array}$ & Others \\
\hline 1987 & 8,200 & 14,500 & 3,300 & 500 & 50 & 50 \\
\hline 1988 & 19,400 & 47,600 & 10,900 & 1,400 & 50 & 40 \\
\hline 1989 & 72,500 & 98,100 & 10,800 & 6,800 & 14,000 & 70 \\
\hline 1990 & 201,300 & 148,000 & 6,800 & 14,300 & 4,200 & 2,600 \\
\hline $1991^{*}$ & 197,000 & 148,600 & 3,400 & 13,000 & 7,400 & 1,800 \\
\hline
\end{tabular}

grew to 1,365 , in 1989 to 6,791 , and in 1990 to 14,300 . Since then, approximately 15,000 immigrants have been received in Greece annually (see tables 1 and 4). Greek officials anticipate that 100,000 additional Pontic Greeks will emigrate over the next several years and possibly more if conditions in the former U.S.S.R. continue to deteriorate.

\section{Evangelical and Pentecostal Emigration'}

The second group to join the exodus around 1985 was comprised of Evangelicals and Pentecostals, members of a conservative branch of Russian fundamentalist Christianity. An estimated half million of them live in the U.S.S.R. today, where they work mainly in agriculture and industry. At various times they have been persecuted, particularly by Stalin and Khrushchev. In the 1980s, several developments converged to initiate their emigration from the U.S.S.R. One was their lingering resentment over past mistreatment, distrust of the Soviet government despite the relaxation of political repression by Gorbachev, and a fear that his liberal reforms would be followed by a new wave of repression predicted in their sacred beliefs.

Another was a conviction that the U.S.S.R. would be severely punished by God for its sinfulness, and they wanted to leave before this calamity occurred. Some Evangelicals and Pentecostalssimply wanted to escape the atheistic influences of Soviet society and to live and worship freely, despite the adoption of a newlaw providing for religious freedom in the U.S.S.R., which they did not trust.

Against this background, three events led directly to efforts by the Evangelicals and Pentecostals to leave the U.S.S.R. One was the conclusion of the Helsinki accords in 1975, which committed the Soviet Union as a signatory to comply with international norms of human rights, including freedom of movement. The second was the example of Soviet Jews and Germans who were emigrating to the West in increasing numbers in the 1970s and 1980s. The third was the notoriety given to the "Siberian Seven" - the Pentecostal Vashchenko family who took refuge in 
the American embassy in Moscow in 1978 and who were permitted to emigrate to the United States six years later. Encouraged by their success, in $1985 \mathrm{sev}$ eral Pentecostal families obtained photocopies of vyzovs (invitations) used by Soviet Jews for emigration to Israel and brazenly applied to emigrate to the Jewish state at the Dutch embassy in Moscow, which served as a proxy for the Israeli embassy, since the U.S.S.R. had broken off diplomatic relations with Israel during the 1967 Six-Day War. Curiously and inexplicably, their petitions were approved by the Dutch, Israeli and Soviet authorities, and they left the U.S.S.R. officially as part of a Jewish contingent. When they reached Vienna, where transit was provided for Jews en route to Israel, they asked to go as refugees to the United States instead and were admitted by the American government under its then liberal asylum policy.

From 1985 to 1988 , only 100 Evangelicals and Pentecostals left the U.S.S.R., but in 1989 the number grew to nearly 14,000 as the Dutch, Israeli, American and Soviet governments continued the charade, the first three out of humanitarian motives, the U.S.S.R. for still unknown reasons. When new restrictive U.S. immigration regulations went into effect in 1990, however, the number of Evangelicalsand Pentecostals admitted to the United States declined along with those of Jews and Armenians, butbetween 1985 and 1991, 25,700Soviet Christians succeeded in leaving the U.S.S.R. (see Table 2).

\section{Soviet Emigration Policy ${ }^{10}$}

Turning to the question of Soviet emigration policy, what has this policy been over the forty-five years of the movement, and how and why has it changed since 1948? Why were some groups but not others permitted to leave the U.S.S.R. despite official opposition to free movement? What similarities and differences have there been in the Soviet government's treatment of the several emigrant groups and what accounts for these similarities and differences?

Important and interesting as these questions are, the fact is that there are no precise answers to them, for the Soviet leaders have never publicly explained their policies, reasons for which must be inferred indirectly from other evidence. Broadly speaking, certain parallels and similarities may be seen in the treatment of the three main emigrant groups at various times, suggesting that Soviet policy towards them was determined by broad general factors rather than by special considerations depending upon the nationality involved, as it has been claimed by some authors, particularly those dealing with Jewish emigration.

For example, during the first stage of the Third Emigration (1948-70), Soviet policy towards all three groups was the result of foreign intervention-from Israel on behalf of the Jews, from West Germany on behalf of the Germans, and from France on behalf of the Armenians, as it has been seen. Despite ideological and political opposition to emigration, theSoviet government allowed a modest exodus of the three groups in order to placate these governments, but disguised its capitulation and prevented setting a precedent by justifying the departures on the grounds of family reunification or repatriation, as mentioned earlier. Influencing these decisions was the fact that the 1950s and 1960s were a time of dislocation and massive postwar population transfers, into which the exodus of a few thousand Jews, Germans and Armenians merged without undue official concern. Moreover, in the case of Jews and Germans, most of the emigrants were elderly or infirm persons of little value to the Soviets-and, indeed, liabilities as pensioners.

During the second stage of the movement (1971-80), three common factors also appear to have influenced Soviet policy towards Jewish and German emigrations, though quite different considerations underlay policy towards Armenians. The common factors affecting Jews and Germans were certain internal Soviet developments, the actions of Western governments on behalf of the two emigrant groups, and the influence of Western public opinion.

One internal Soviet development was the relaxation of political controls that paralleled detente with the West af- ter 1971. This was manifested in part by the liberalization of emigration for Jews and Germans, many of whose questionable claims to family reunification were winked at by the authorities. A second internal development was a new assertiveness and activism on the part of prospective Jewish and German emigrants, who staged daring demonstrations, presented petitions and demands, and openly courted foreign support from various governments and public figures. The Soviet government reacted to this unaccustomed defiance with surprising moderation and permitted increasingly large quotas of emigrants to leave throughout the seventies, as seen. At the same time, the United States (which supplanted Israel as the main champion of theSovietJews) and West Germany used various forms of coercion and blandishments to persuade Moscow to liberalize emigration.

The relations between the U.S.S.R. and the West during the 1970s has been widely discussed elsewhere and need not be reviewed here. Suffice it to say that Western measures included, among others, the offer or withholding of trade and technological exchanges; the linkage of Soviet conduct concerning human rights to the resolution of other international issues; and public exposure of political repression in the U.S.S.R., to which the Soviet government was sensitive in those years.

The third factor was the impact of Western public opinion, to which the Soviet leaders appeared to be responsive for a time. Though its precise effect is difficult to gauge, there is reason to believe that wide press coverage of the issue of human rights in the U.S.S.R. in general and of emigration in particular; activities of Western supporters of the emigrants, including demonstrations before Soviet embassies and confrontations with visiting Soviet representatives; parliamentary declarations and denunciations; public reminders of Soviet obligations under the Charter of the United Nations and the Helsinki accords; and even criticism by European communists all helped to persuade the Soviet leaders to liberalize emigration policy between 1971 and 1980. 
With the erosion of detente after 1980 , however, the Soviet authorities became indifferent to their "image" in the West and Western public opinion ceased to exercise an influence. With the emergence of a reformist policy under Gorbachev, however, Western public opinion again began to figure importantly in Soviet internal and foreign relations, and a liberalization of Jewish and German emigration followed, as mentioned earlier.

While these factors help to account for Soviet policy towards Jewish and German emigration, they do not explain Armenian emigration. Unlike the Jews and Germans, the Armenians had no foreign country or lobbyists in the West working on their behalf. On the contrary, the international Armenian diaspora deplored emigration from the Armenian S.S.R., which it considered its national homeland and religious centre and wanted to see strengthened. Why then did the Soviet authorities permit thousands of Armenians to leave during the 1970 s in the absence of the forces that shaped their policy towards Jews and Germans?

There is no answer to this question, for even members of Armenian communities in the West cannot explain it. Only possible reasons have been suggested. These include Moscow's benign neglect of Soviet Armenia; a desire by the Soviet government and Armenian officials to be rid of troublesome elements; an attempt to dispel the impression that the Soviets had "caved in" to Western pressure on behalf of Jews and Germans by permitting anothernationality "eligible" for family reunification to leave; efforts by the Soviet leaders to court Armenian goodwill at home and abroad to encourage tourism and the hard currency it earned as well as foreign investment in the Armenian S.S.R.; and concern over the strategic importance of Armenia in the event of a conflict with neighbouring Turkey or a flare-up of the volatile Middle East.

Whatever the reasons, Soviet policy towards Armenians changed after 1980, as it did for Jews and Germans, and emigration levels declined from the high point reached in that year (see Table 1).
The main reason for the cutback undoubtedly was the breakdown of detente, and the resumption of Armenian emigration after 1987 was presumably due to the thaw under Gorbachev, as was the case with Jews and Germans (see Table 4).

The motives of Soviet policy towards the Pontic Greeks, Evangelicals and Pentecostals are as obscure as those towards the Armenians. It is known that the Greek government intervened on behalf of the Pontic Greeks, while the United States actively supported the Christians, and it can only be assumed that there was no reason for Moscow to refuse their emigration in modest numbers and risk alienating Washington and Athens as long as it did not encourage others to leave.

\section{Summary}

The discussion has traced Soviet postwar emigration from its origins through the end of 1991, analysing its causes and dynamics and exploring Soviet emigration policy. Beginning in 1992 the momentous changes that brought about the end of the Soviet Union also effectively ended the Third Emigration per se. Outmigration from the successor states of the formerU.S.S.R. continued apace after 1991, of course, but the causes, composition, patterns, dynamics and directions of the exodus changed so radically that it nolonger resembled the movement until then. Indeed, Western writers began to allude to the start of a new "fourth wave" of post-Soviet emigration in 1992 that was expected to dwarf the Third Emigration and inundate Europe with a horde of refugees who would be joined by a massive flight of others from eastern Europe. ${ }^{11}$

This flood has not materialized thus far, though some observers believe it may yet do so if conditions in the former Soviet Union or eastern Europe deteriorate beyond a point of tolerance. In any case, the distinctive features of the Third Soviet Emigration and the forces that brought it into being and sustained it for more than four decades no longer prevailed after 1991.

This article has sought to illuminate the course and dynamics of the move- ment while it was an active, influential force in Soviet and international affairs and to place it in its proper historical context. It also provides an indispensable background for understanding the continued, albeit altered, flow of population from the Soviet successor states and the possible course of this migration in the foreseeable future.

\section{Notes}

1. I wish to acknowledge the assistance of Robert J. Brym of the Department of Sociology, University of Toronto, who provided invaluable suggestions and read and commented on the text of this article.

2. For a detailed treatment of Soviet emigration and an extensive bibliography on the subject, see Sidney Heitman, The Third Soviet Emigration: Jewish, German, and Armenian Emigration From the USSR Since World War II (Cologne: Bundesinstitut fur ostwissenschaftliche und internationale studien, 1987)

3. Alan Dowty, Closed Borders: The Contemporary Assault on Freedom of Movement (New Haven: Yale University Press, 1987), 68.

4. George Ginsburgs, "Soviet Law and the Emigration of Soviet Jews," Soviet Jewish Affairs, 3, no. 1 (1973): 4

5. The literature on Soviet Jewry and Jewish emigration is voluminous. This section is based on various published accounts, including A. Alexander, Immigration to Israel from the USSR (Tel Aviv: Faculty of Law, Tel Aviv University, 1977); Joel Cang, The Silent Millions: A History of the Jews in the Soviet Union (New York: Taplinger Publishing Co., 1969); Robert O. Freedman, ed., Soviet Jewry in the Decisive Decade, 1971-1980 (Durham: Duke University Press, 1984); William Korey, The Soviet Cage: Antisemitism in Russia (New York: Viking Press, 1973); Thomas E. Sawyer, The Jewish Minority in the Soviet Union (Boulder: Westview Press, 1979); and Victor Zaslavsky and Robert J. Brym, Soviet Jewish Emigration and Soviet Nationality Policy (New York: St. Martin's Press, 1987)

6. This section is based on various published and unpublished sources, including 30 Jahre Lager Friedland (Hanover: Niedersachsischen Minister fur Bundesgelegenheiten, 1975) CDU/CSU Group in the German Bundestag, White Paper on the Human Rights Situation in Germany and of the Germans in Eastern Europe (Bonn: CDU/CSU Group, 1977); Ingeborg Fleischhauer, Die Deutschen im Zarenreich: 200 Jahre deutsch-russischer Kulturgemeinschaft (Stuttgart: Deutsche Verlag Anstalt, 1986); Adam Giesinger, From Catherine to Khrushchev: The Story of Russia's Germans (Saskatchewan: Marian Press, 1974); and Sidney Heitman, The Soviet Germans in the USSR Today (Cologne: Bundesinstitut fur ostwissenschaftliche und internationale studien, 1981) 